and exhorting the Government to resort to its former wise regulations as to exemption for such educational institutions.

Boston, Mass.

M. S. R. JAMEs.

\title{
Correspondence.
}

\section{Quinn-Brown Classification.}

DEAR Sir, - In the number of Thr, Library for March, 1897, Mr. Bond suggested certain alterations in the class letters of the Quinn-Brown classification, which system has been in use at the Kingston-upon-Thames Library since August, 1895.

There is no reason why the alphabet need be used consecutively. The scheme is "neither scientific nor rigid, being simply a framework of suggestions . . . which anyone can elaborate or simplify at pleasure." (LIBRARY, vol. vii., p. 75.)

As "open access" is associated with "Quinn-Brown" at Kingston, we have not experienced the difficulty to which Mr. Bond refers. (Is this mis-pronunciation or mis-hearing confined to letters only? What about numbers?)

As a remedy $I$ would suggest the use of a demand note, which is in every way preferable to the vivâ voce method. It is available for all statistical purposes, and supersedes the troublesome and time-wasting issue recording sheet; moreover, instead of making a separate journey for each book, as must generally be the case where a letter and number have to be retained in the memory, with demand notes it is possible to gather half-a-dozen or more books, for as many borrowers, thus saving both time and labour.

Public Library, Kingston-upon-Thames.

$$
\begin{aligned}
& \text { Yours faithfully, } \\
& \text { BENJAMIN CARTER. }
\end{aligned}
$$

DeAr SiR,-My attention has been called to Mr. Bond's remarks on the Quinn-Brown classification which appeared in THE LiBRARY for March, 1897 . I confess they are not very clear to me. If he nieans that his letters are an improvement in nomenclature for main divisions, I cannot follow him, inasmuch as, by his plan, important classes like Poetry, Literature, Language, Biography, Science and Theology are disguised under initialisms which in no way distinguish them. If he means that his distribution of classes is an improvement, there, again, I am unable to appreciate any advantage. Such a class as his C, to my mind, is misleading, even in a numerically-arranged library, because it simply jumbles together almost every kind of subject-matter. What advantage arises from placing Homer in C.-Classics, instead of in D-Poetry, or putting Aristotle, Livy, Plato and Xenophon also in such a heterogeneous division? Even to ordinary readers, such an entry as "Herodotus; transl. by Cary, 1892, C 149," can convey nothing save a vague idea that the author is either a classic (i.e., ancient Greek or Latin author), writing on any topic under the sun; an author of general literature; or writer on language. Assistants would also be confused by such a slapdash classification. The mere naming of main classes has nothing to do with classification, and I suggest to Mr. Bond that, if he is anxious to avoid mistakes arising from slurred or imperfect pronunciation of initial 
letters, he might use the names of the Greek alphabet. There could be no mistake. if a reader asked for Delta I42, meaning Shakespeare's Plays. When Mr. Bond attempts to strictly classify and amalgamate the History and Biography on his shelves, he will find that they do not combine readily. There is no affinity between place and personality; but there is between history of place and description of place, hence the reason for the Quinn-Brown classes B and C. Yours truly,

\section{Clerkenwell Public Library.}

JAMgS D. BROWN.

\section{Classified Catalogues.}

Dear SIR,-In looking over last year's volume we find that Mr. Ogle calls attention to a paper of ours and corrects us upon "one or two errors of fact" in our allusions to the "Bootle Free Public Library Catalogue, 1896." We are sorry if we have misrepresented Mr. Ogle in any way, but we confess ourselves unable to understand in what we have done so.

"There is no 'preface statement that books on each subject are all gathered together at one place," we are informed. The words used in the preface are: "Each subject-entry is now a list of titles in brief of all works the library contains specially relating thereto." What does this sentence mean, if it does not bear the interpretation we have adopted ?

Mr. Ogle further tells us that he has not published a classification in the catalogue, though pages 272 to $28 \mathrm{I}$ are devoted to a "Classified List of Subject-headings," arranged under the following main classes :-

I Biography. 2 Word Lore. 3 Religious Lore. 4 Social

Lore. 5 Geography, \&c. 6 Mind Lore. 7 Art Lore. 8 Nature

Lore. 9 Industrial Lore. Io Unclassified Items.

And to it the preface directs the attention of the "methodical student." If this is not a systematic classification, it is a remarkably close imitation. However, we accept Mr. Ogle's statement that it is not a classification, while still retaining our opinion that, whatever else it may be, it is a "wild and weird production."

Mr. Ogle suggests that in future articles we should "speak to the point." We are not aware that we wandered from it, but we cannot, of course, be responsible for Mr. Ogle's inability to see the point. He complains that we "discuss at length such subjects as annotations and abbreriations of titles, as though these matters had a bearing in settling the question of a classified or alphabetical arrangement of subject names in a list of books." Considering that our article was an attempt at an exposition of descriptive class lists, it certainly seems to us-in our benighted stupidity, no doubt-that annotations and title entries are not absolutely alien to the theme.

Yours faithfully, JAMRS D. BROWN.

L. STANLEY Jast.

To the Editor of THE LIBRARY.

The Late Mr. J. W. Haggerston : A Defreck

Drar Sir, - The many friends of the late Mr. J. W. Haggerston, of Newcastle, and the perhaps more numerous admirers of the alert ingenious, and thoroughly up-to-date librarian of Clerkenwell (Mr. 